\title{
Influence of the Microalga Chlorella vulgaris on the Growth and Metabolic Activity of Lactobacillus spp. Bacteria
}

\author{
Sylwia Ścieszka *(1) and Elżbieta Klewicka@ \\ Institute of Fermentation Technology and Microbiology, Lodz University of Technology, Wólczańska 171/173, \\ 90-924 Łódź, Poland; elzbieta.klewicka@p.lodz.pl \\ * Correspondence: sylwia.scieszka@edu.p.lodz.pl
}

Received: 25 June 2020; Accepted: 17 July 2020; Published: 20 July 2020

\begin{abstract}
The aim of this study was to evaluate the effect of the algae Chlorella vulgaris on the growth, acidifying activity, proportion of lactic acid isomers, and enzymatic profile of Lactobacillus brevis (ŁOCK 0944, ŁOCK 0980, ŁOCK 0992, and MG451814) isolated from vegetable silages. The results indicated that adding algae at concentrations of $0.1 \%(w / v)$ and $1.5 \%(w / v)$ to the Lactobacillus spp. growth medium accelerated the growth of bacteria and thus shortened their phase of logarithmic growth. The acidifying activity of the tested Lactobacillus brevis increased with an increased concentration of algae. Lactobacillus spp. cultured in the presence of Chlorella vulgaris showed higher production of L-lactic acid and lower D-lactic acid production. Moreover, the addition of algae changed the enzymatic activity of lactic acid bacteria; for instance, Lactobacillus brevis ŁOCK 0980 demonstrated more enzymatic activity of valine arylamidase, $\alpha$-galactosidase, and $\alpha$-glucosidase. Combining Lactobacillus brevis with the algae Chlorella vulgaris allows for the creation of innovative, functional products which confer favorable properties to the final product and open new horizons for the food industry.
\end{abstract}

Keywords: microalga Chlorella vulgaris; lactic acid bacteria; total titratable acidity; enzymatic profile; lactic acid isomers; Lactobacillus brevis; algae

\section{Introduction}

Nowadays consumers demand innovative products, and interest in algae has increased significantly. Therefore, several companies have gotten involved in developing foods containing microalgae [1]. Some algae species, such as Chlorella, which have great potential for the human diet [2], are already commercially used in foods [3]. Examples of food products with Chlorella include organic algae drink and sea-salt-flavored seaweed crackers (Helga brand) produced by company Evasis Edibles (Austria), crispy matcha biscuits by Tohato (Japan), baked bean crackers in the shape of edamame beans from Ginbi (Japan), and greens organic bar (Raw Sun Bite brand) produced by Lavica Food (Poland) [1]. Moreover, several studies have indicated that microalgae can be introduced to food products with high sensorial and nutritional quality; for instance, Chlorella vulgaris was incorporated into wheat flour dough and bread [4], breadsticks [5], and cookies [6]. However, only a few studies so far have focused on the practical use of algae and fermented food. Popular fermented products enriched with Chlorella are dairy products, such as probiotic fermented milk [7] and various types of cheese (Appenzeller cheese [8] and functional spreadable processed cheese [9]).

The most important microorganisms used in food fermentation are lactic acid bacteria (LAB) [10], while Lactobacillus spp. are the utmost studied microorganisms and used as starter cultures [11]. Moreover, 35 Lactobacillus species meet the European Food Safety Authority (EFSA) criteria for a 
qualified presumption of safety (QPS) [12]. Due to their cholesterol-lowering properties [13,14], anti-inflammatory [15], antioxidant [16], and antagonistic activity [17-19], LAB are used in the prevention and treatment of many diseases, such as irritable bowel syndrome [20], dysbiosis [18], urinary tract infections [17], antibiotic-associated diarrhea, infectious diarrhea [21], allergies [15], and atopic dermatitis [22,23].

Lactic acid bacteria have also been used for the fermentation of macroalgae (seaweeds) and microalgae, for instance, Undaria pinnatifida (Phaeophyta) [24], Arthrospira platensis (Spirulina) [25], edible Irish brown seaweeds (Himanthalia elongata, Laminaria digitata, and Laminaria saccharina) [26], and Chlorella vulgaris [27].

Both Chlorella and Lactobacillus fall into the category of Generally Recognized as Safe (GRAS) [28,29], and consuming them offers various health benefits $[30,31]$. Combining algae with LAB allows for the creation of a functional product with all essential nutrients necessary for the correct and healthy functioning of the body.

The aim of this study was to evaluate the effect of algae Chlorella vulgaris on the growth, acidifying (metabolic) activity, and enzymatic profile of four Lactobacillus brevis strains.

\section{Materials and Methods}

\subsection{Bacterial Strains}

Four strains belonging to the species Lactobacillus brevis which were isolated from vegetable silages were used for the study: Lactobacillus brevis ŁOCK 0944, Lactobacillus brevis ŁOCK 0980, and Lactobacillus brevis ŁOCK 0992 - deposited with the Pure Culture Collection of Industrial Microorganisms of the Institute of Fermentation Technology and Microbiology ŁOCK 105, at Lodz University of Technology (Poland)—and Lactobacillus brevis MG451814, whose nucleotide sequence is on deposit in the GenBank National Centre for Biotechnology Information database under the accession number MG451814. Lactobacillus brevis ŁOCK 0944 has a patent deposit number (B/00035) in the Polish Collection of Microorganisms [32].

Stock cultures of Lactobacillus brevis strains were cultured in MRS broth (De Man, Rogosa, and Sharpe, Merck, Germany) at $30^{\circ} \mathrm{C}$ for $24 \mathrm{~h}$.

\subsection{The Research Material}

The research material was powdered Chlorella vulgaris from Bellis Food (BellisPharma Sp. z o. o., Jarosław, Poland). The algae concentrations used in the study were $0.1 \%(w / v)$ and $1.5 \%(w / v)$.

\subsection{Statistical Analysis}

All experiments were performed in three independent trials. All data are expressed as the arithmetic means of the three repetitions with standard deviations. To determine the statistical significance of differences between the results, the ANOVA test of differences was used, at a significance level of $p<0.05$. The software Origin Pro 2017 was used for analysis.

\subsection{Growth of Lactobacillus brevis Cultured in the Presence of Chlorella vulgaris}

The effect of algae on the growth of Lactobacillus brevis was assessed by incubating the 24-h Lactobacillus brevis strains with a density of $10^{7} \mathrm{CFU} / \mathrm{mL}$, in MRS broth (Merck, Germany), in the presence of algae at concentrations of $0.1 \%(w / v)$ and $1.5 \%(w / v)$. The control samples were LAB cultures without algae. The growth of the Lactobacillus brevis strains was investigated by the plate method at specified intervals $(0,4,8,12,18,24$, and $48 \mathrm{~h})$ during incubation at $30^{\circ} \mathrm{C}$. After incubation, the cultures were serially diluted, spread on MRS agar plates, and incubated for $48 \mathrm{~h}$ at $30^{\circ} \mathrm{C}$. The results are presented as log colony-forming units (CFU) per milliliter. 


\subsection{Acidifying Activity of Lactobacillus spp.}

Determination of the total titratable acidity produced by Lactobacillus brevis was performed by incubation 24-h Lactobacillus strains with $0.1 \%(w / v)$ and $1.5 \%(w / v)$ and without (control samples) Chlorella vulgaris and titration samples (after $0,4,8,12,18,24$, and $48 \mathrm{~h}$ of incubation at $30^{\circ} \mathrm{C}$ ), with a 0.1- $\mathrm{N}$ aqueous solution of $\mathrm{NaOH}$, in the presence of phenolphthalein. The total titratable acidity is expressed as $\mathrm{mL}$, and $0.1-\mathrm{M} \mathrm{NaOH}$ was used for titration of the $1 \mathrm{~mL}$ of sample.

\subsection{Proportion of Lactic Acid Isomers}

The D- and L-isomers of lactic acid produced by the four strains of Lactobacillus brevis were evaluated by using the L-/D- Lactic acid assay (Megazyme International Ireland, Bray, Wicklow, Ireland). To check the impact of algae on the chiral purity of the LAB, the bacteria strains were cultured in the presence of Chlorella vulgaris, at a concentration of $1.5 \%(w / v)$ for $24 \mathrm{~h}$. The content of L- and D-lactic acid was determined by measuring the increase of NADH at $340 \mathrm{~nm}$.

\subsection{Measurement of the Enzymatic Profile}

The enzymatic profiles of the selected Lactobacillus strains were characterized by using the $\mathrm{API}^{\circledR}$ ZYM system (BioMérieux, France). To examine the effect of algae on LAB enzymatic activity, Chlorella vulgaris was added to the tested samples at a concentration of $1.5 \%(w / v)$. Each well was charged with $65 \mu \mathrm{L}$ of a LAB cultured with or without algae and incubated at $30^{\circ} \mathrm{C}$ for $4 \mathrm{~h}$. After incubation, the reagents ZYM A and ZYM B were added to each well, according to the manufacturer's instructions, and left for $5 \mathrm{~min}$, to allow the color to develop. Then the strips were placed under a powerful light source for $10 \mathrm{~s}$. The enzymatic activity was evaluated based on the API ${ }^{\circledR} \mathrm{ZYM}$ scale provided by the manufacturer, from 0 (no activity) to 5 .

\section{Results}

\subsection{The Impact of Chlorella vulgaris on the Growth of Lactobacillus spp.}

The growth of the Lactobacillus brevis strains in the presence of Chlorella vulgaris at concentrations of $0.1 \%(w / v)$ and $1.5 \%(w / v)$ was tested by the plate method at specified times $(0,4,8,12,18,24$, and $48 \mathrm{~h})$. The results are presented in Figure 1 as the mean values of three independent trials in log CFU/mL.

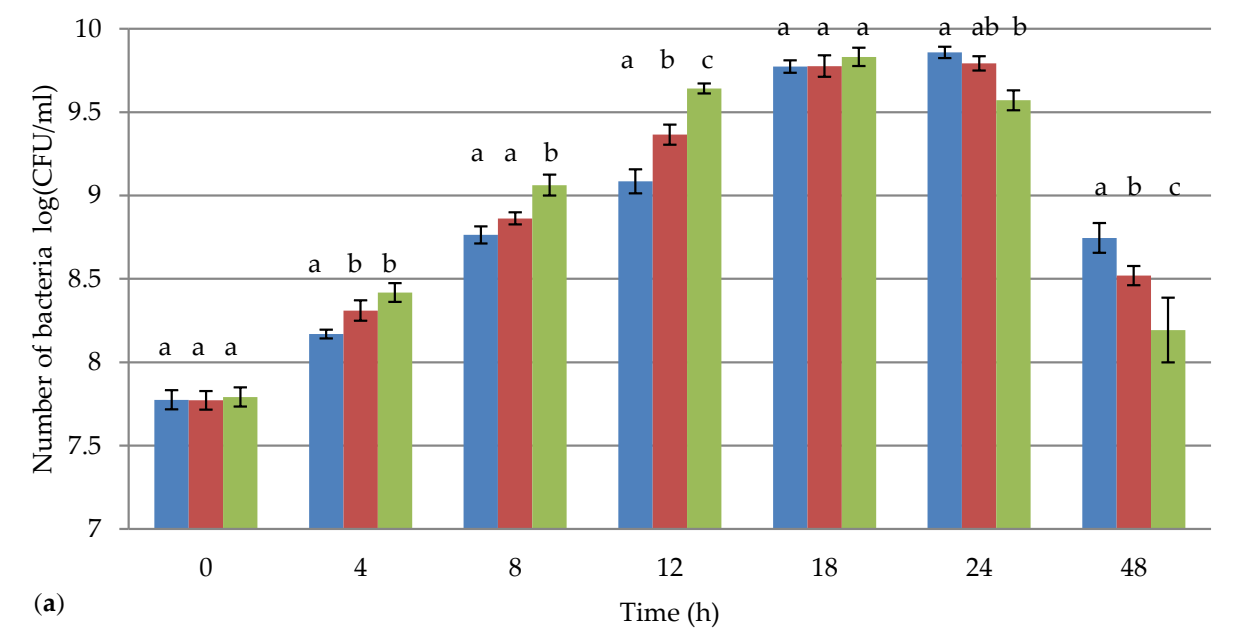

Figure 1. Cont. 

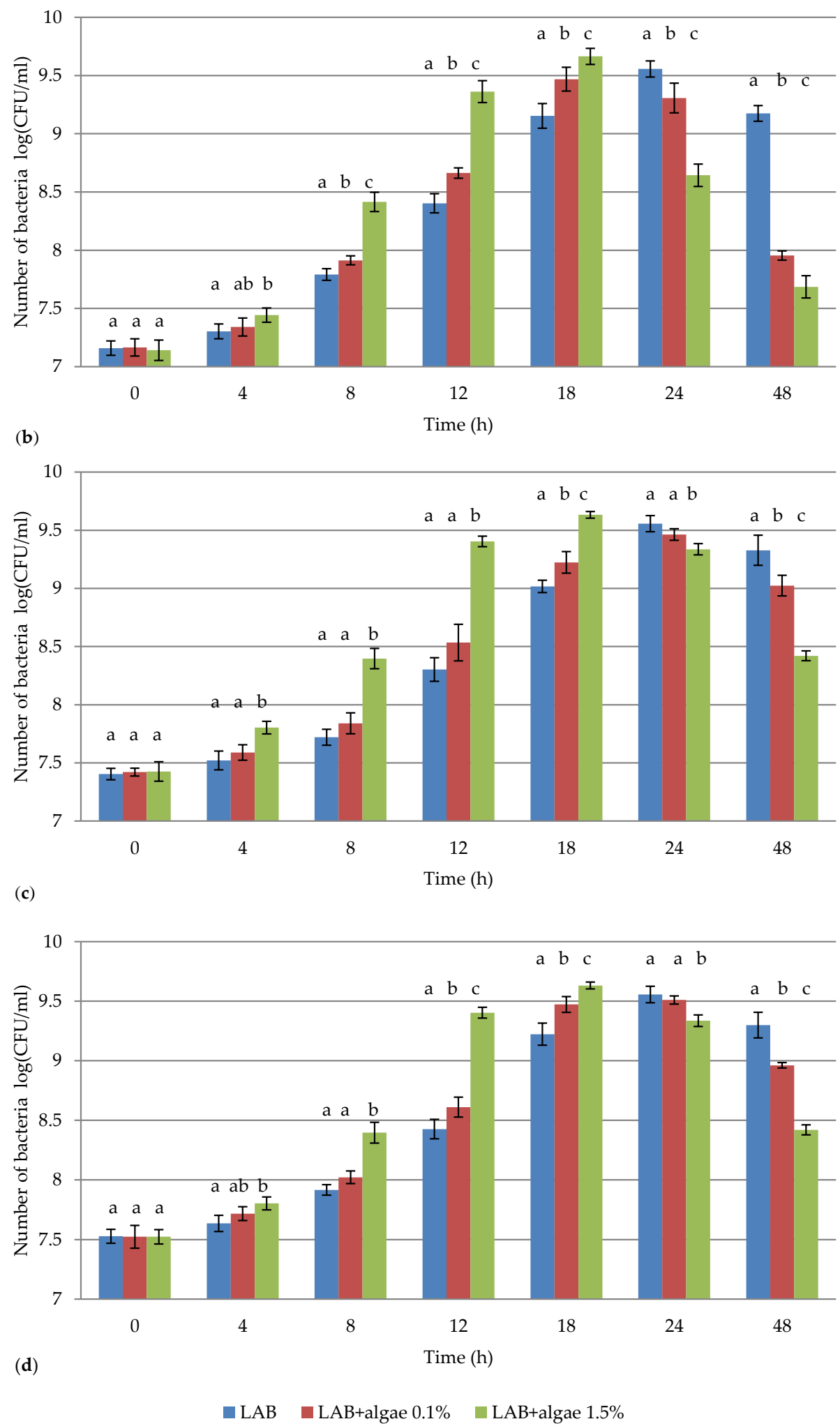

Figure 1. The survival of Lactobacillus brevis (a) ŁOCK 0944 (b) ŁOCK 0980 (c) ŁOCK 0992, and (d) MG451814 in the presence of the algae Chlorella vulgaris, at concentrations of $0.1 \%(w / v)$ and $1.5 \%(w / v)$. Explanatory notes: the figure shows mean values (bars) and standard deviations (line segments); LAB-lactic acid bacteria; $a, b, c$ - the statistically significant differences between samples of the same strains within one time interval; $p<0.05 ; n=3$. 
The results showed that, at concentrations of $0.1 \%(w / v)$ and $1.5 \%(w / v)$, Chlorella vulgaris had an impact on the number of tested LAB. Statistically significant differences were observed between the control samples and the samples with algae added at a concentration of $1.5 \%(w / v)$ at all tested hours. The addition of algae at a concentration of $1.5 \%(w / v)$ had the least impact on the growth of Lactobacillus brevis ŁOCK 0944: After $12 \mathrm{~h}$ of culturing, the difference between the control sample and the sample with algae was $0.56 \log \mathrm{CFU} / \mathrm{mL}$, whereas, in the case of the Lactobacillus brevis ŁOCK 0992, the difference in bacterial survival was the largest, at $1.10 \log \mathrm{CFU} / \mathrm{mL}$. Moreover, only for Lactobacillus brevis ŁOCK 0944 after $18 \mathrm{~h}$ of culturing were there no statistically significant differences between all samples.

For all tested Lactobacillus brevis strains, the dynamic growth of biomass of the bacteria cultured in the presence of Chlorella vulgaris was observed for the first $18 \mathrm{~h}$ of culturing. However, for the control samples-which were not enriched with algae-an increase in the number of tested LAB was observed after $24 \mathrm{~h}$ of culturing. Therefore, Chlorella vulgaris accelerated the growth of Lactobacillus brevis, thus shortening their phase of logarithmic growth.

\subsection{The Effect of Chlorella vulgaris on the Total Titratable Acidity of Lactobacillus spp.}

The acidifying activity of the tested Lactobacillus brevis strains cultured with and without the algae Chlorella vulgaris, at concentrations of $0.1 \%(w / v)$ and $1.5 \%(w / v)$, during $48 \mathrm{~h}$ of incubation at $30{ }^{\circ} \mathrm{C}$, is presented in Tables $1-4$. The total acidity is expressed as $\mathrm{mL} 0.1-\mathrm{M} \mathrm{NaOH} / 1 \mathrm{~mL}$ of sample.

Table 1. Effect of algae Chlorella vulgaris on the total titratable acidity of Lactobacillus brevis ŁOCK 0944.

\begin{tabular}{cccc}
\hline Time (h) & LAB & LAB+ Algae 0.1\% & LAB+ Algae 1.5\% \\
\hline & & Total Acidity (mL 0.1-M NaOH/1 $\mathbf{~ m L )}$ \\
\hline 0 & $0.70 \pm 0.05^{\mathrm{a}}$ & $0.80 \pm 0.05^{\mathrm{b}}$ & $0.90 \pm 0.05^{\mathrm{c}}$ \\
4 & $0.80 \pm 0.05^{\mathrm{a}}$ & $0.90 \pm 0.05^{\mathrm{b}}$ & $1.00 \pm 0.05^{\mathrm{c}}$ \\
8 & $1.20 \pm 0.10^{\mathrm{a}}$ & $1.30 \pm 0.10^{\mathrm{b}}$ & $1.45 \pm 0.10^{\mathrm{c}}$ \\
12 & $1.80 \pm 0.10^{\mathrm{a}}$ & $1.95 \pm 0.15^{\mathrm{b}}$ & $2.20 \pm 0.10^{\mathrm{c}}$ \\
18 & $2.40 \pm 0.05^{\mathrm{a}}$ & $2.45 \pm 0.05^{\mathrm{a}}$ & $2.55 \pm 0.05^{\mathrm{b}}$ \\
24 & $2.50 \pm 0.05^{\mathrm{a}}$ & $2.50 \pm 0.05^{\mathrm{a}}$ & $2.60 \pm 0.00^{\mathrm{b}}$ \\
48 & $2.50 \pm 0.05^{\mathrm{a}}$ & $2.50 \pm 0.00^{\mathrm{a}}$ & $2.65 \pm 0.05^{\mathrm{b}}$ \\
\hline
\end{tabular}

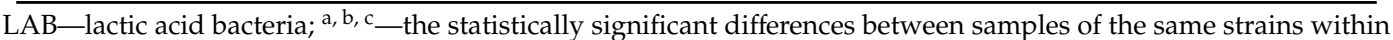
one time interval; $p<0.05$; the number of samples $(n=3)$.

Table 2. Effect of algae Chlorella vulgaris on the total titratable acidity of Lactobacillus brevis ŁOCK 0980.

\begin{tabular}{cccc}
\hline Time (h) & LAB & LAB+ Algae 0.1\% & LAB+ Algae 1.5\% \\
\hline \multicolumn{4}{c}{ Total Acidity (mL 0.1-M NaOH/1 mL) } \\
\hline 0 & $0.70 \pm 0.00^{\mathrm{a}}$ & $0.70 \pm 0.05^{\mathrm{b}}$ & $0.80 \pm 0.05^{\mathrm{c}}$ \\
4 & $0.70 \pm 0.05^{\mathrm{a}}$ & $0.80 \pm 0.05^{\mathrm{b}}$ & $0.90 \pm 0.05^{\mathrm{c}}$ \\
8 & $0.90 \pm 0.10^{\mathrm{a}}$ & $0.95 \pm 0.15^{\mathrm{b}}$ & $1.25 \pm 0.10^{\mathrm{c}}$ \\
12 & $1.20 \pm 0.10^{\mathrm{a}}$ & $1.30 \pm 0.10^{\mathrm{b}}$ & $1.55 \pm 0.15^{\mathrm{c}}$ \\
18 & $1.45 \pm 0.05^{\mathrm{a}}$ & $1.60 \pm 0.05^{\mathrm{b}}$ & $1.85 \pm 0.00^{\mathrm{c}}$ \\
24 & $1.60 \pm 0.05^{\mathrm{a}}$ & $1.70 \pm 0.00^{\mathrm{b}}$ & $1.90 \pm 0.05^{\mathrm{c}}$ \\
48 & $1.60 \pm 0.00^{\mathrm{a}}$ & $1.70 \pm 0.05^{\mathrm{b}}$ & $1.90 \pm 0.05^{\mathrm{c}}$ \\
\hline
\end{tabular}

$\mathrm{LAB}$-lactic acid bacteria; ${ }^{\mathrm{a}, \mathrm{b}, \mathrm{c} \text { - }}$-the statistically significant differences between samples of the same strains within one time interval; $p<0.05$; the number of samples $(n=3)$. 
Table 3. Effect of algae Chlorella vulgaris on the total titratable acidity of Lactobacillus brevis ŁOCK 0992.

\begin{tabular}{cccc}
\hline Time (h) & LAB & LAB+ Algae 0.1\% & LAB+ Algae 1.5\% \\
\hline \multicolumn{4}{c}{ Total Acidity (mL 0.1-M NaOH/1 mL) } \\
\hline 0 & $0.70 \pm 0.05^{\mathrm{a}}$ & $0.70 \pm 0.05^{\mathrm{b}}$ & $0.85 \pm 0.05^{\mathrm{c}}$ \\
4 & $0.75 \pm 0.05^{\mathrm{a}}$ & $0.80 \pm 0.05^{\mathrm{b}}$ & $1.00 \pm 0.10^{\mathrm{c}}$ \\
8 & $0.95 \pm 0.10^{\mathrm{a}}$ & $1.05 \pm 0.10^{\mathrm{b}}$ & $1.40 \pm 0.05^{\mathrm{c}}$ \\
12 & $1.30 \pm 0.15^{\mathrm{a}}$ & $1.45 \pm 0.10^{\mathrm{b}}$ & $1.80 \pm 0.15^{\mathrm{c}}$ \\
18 & $1.70 \pm 0.05^{\mathrm{a}}$ & $1.90 \pm 0.05^{\mathrm{b}}$ & $2.30 \pm 0.05^{\mathrm{c}}$ \\
24 & $2.40 \pm 0.05^{\mathrm{a}}$ & $2.55 \pm 0.05^{\mathrm{b}}$ & $2.70 \pm 0.00^{\mathrm{c}}$ \\
48 & $2.45 \pm 0.05^{\mathrm{a}}$ & $2.60 \pm 0.05^{\mathrm{b}}$ & $2.70 \pm 0.05^{\mathrm{c}}$ \\
\hline
\end{tabular}

$\mathrm{LAB}-$ lactic acid bacteria; ${ }^{\mathrm{a}, \mathrm{b}, \mathrm{c} \text { - }}$ the statistically significant differences between samples of the same strains within one time interval; $p<0.05$; the number of samples $(n=3)$.

Table 4. Effect of algae Chlorella vulgaris on the total titratable acidity of Lactobacillus brevis ŁOCK MG451814.

\begin{tabular}{cccc}
\hline Time (h) & LAB & LAB+ Algae 0.1\% & LAB+ Algae 1.5\% \\
\hline & \multicolumn{3}{c}{ Total Acidity (mL 0.1-M NaOH/1 $\mathbf{~ m L )}$} \\
\hline 0 & $0.70 \pm 0.05^{\mathrm{a}}$ & $0.70 \pm 0.05^{\mathrm{b}}$ & $0.90 \pm 0.00^{\mathrm{c}}$ \\
4 & $0.75 \pm 0.05^{\mathrm{a}}$ & $0.75 \pm 0.05^{\mathrm{b}}$ & $0.95 \pm 0.05^{\mathrm{c}}$ \\
8 & $0.80 \pm 0.05^{\mathrm{a}}$ & $0.90 \pm 0.10^{\mathrm{b}}$ & $1.10 \pm 0.15^{\mathrm{c}}$ \\
12 & $0.85 \pm 0.05^{\mathrm{a}}$ & $1.10 \pm 0.10^{\mathrm{b}}$ & $1.30 \pm 0.10^{\mathrm{c}}$ \\
18 & $0.90 \pm 0.10^{\mathrm{a}}$ & $1.30 \pm 0.15^{\mathrm{b}}$ & $1.45 \pm 0.00^{\mathrm{c}}$ \\
24 & $1.40 \pm 0.05^{\mathrm{a}}$ & $1.60 \pm 0.05^{\mathrm{b}}$ & $1.80 \pm 0.05^{\mathrm{c}}$ \\
48 & $1.45 \pm 0.05^{\mathrm{a}}$ & $1.65 \pm 0.05^{\mathrm{b}}$ & $1.80 \pm 0.05^{\mathrm{c}}$ \\
\hline
\end{tabular}

$\mathrm{LAB}$-lactic acid bacteria; ${ }^{a}, \mathrm{~b}, \mathrm{c}$ - the statistically significant differences between samples of the same strains within one time interval; $p<0.05$; the number of samples $(n=3)$.

The results indicated that the acidifying activity of Lactobacillus brevis varied depending on the strains of bacteria used. The highest total acidity was obtained for Lactobacillus brevis ŁOCK 0944

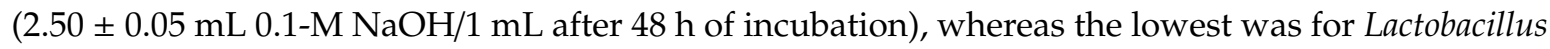
brevis ŁOCK MG451814 (1.45 $\pm 0.05 \mathrm{~mL} 0.1-\mathrm{M} \mathrm{NaOH} / 1 \mathrm{~mL}$ after $48 \mathrm{~h}$ of incubation).

The acidifying activity of the tested Lactobacillus brevis strains increased with an increased concentration of algae. Statistically significant differences between samples with different algae concentrations were visible already at $0 \mathrm{~h}$, because algae acidify the environment. The highest titratable acidity for all tested LAB occurred in the first $24 \mathrm{~h}$ of incubation, and the maximum was reached after $48 \mathrm{~h}$. The highest total acidity obtained from a LAB cultured in the presence of Chlorella vulgaris was from Lactobacillus brevis ŁOCK $0992(2.70 \pm 0.05 \mathrm{~mL}$ 0.1-M NaOH/1 mL). Statistically significant differences in total activity between the control samples and the samples with algae within one time interval were observed for almost all tested LAB. Only for Lactobacillus brevis ŁOCK 0944 there were no statistically significant differences between the control sample and the sample with algae added at a concentration of $0.1 \%(w / v)$, after $18 \mathrm{~h}$ of incubation.

\subsection{Influence of Chlorella vulgaris on $\mathrm{D}$ - and $\mathrm{L}$-Lactic Acid Production by Lactobacillus spp.}

The effect of algae at a concentration of $1.5 \%(w / v)$ on $\mathrm{D}-/ \mathrm{L}-$ lactic acid production by Lactobacillus brevis is presented in Figure 2. 


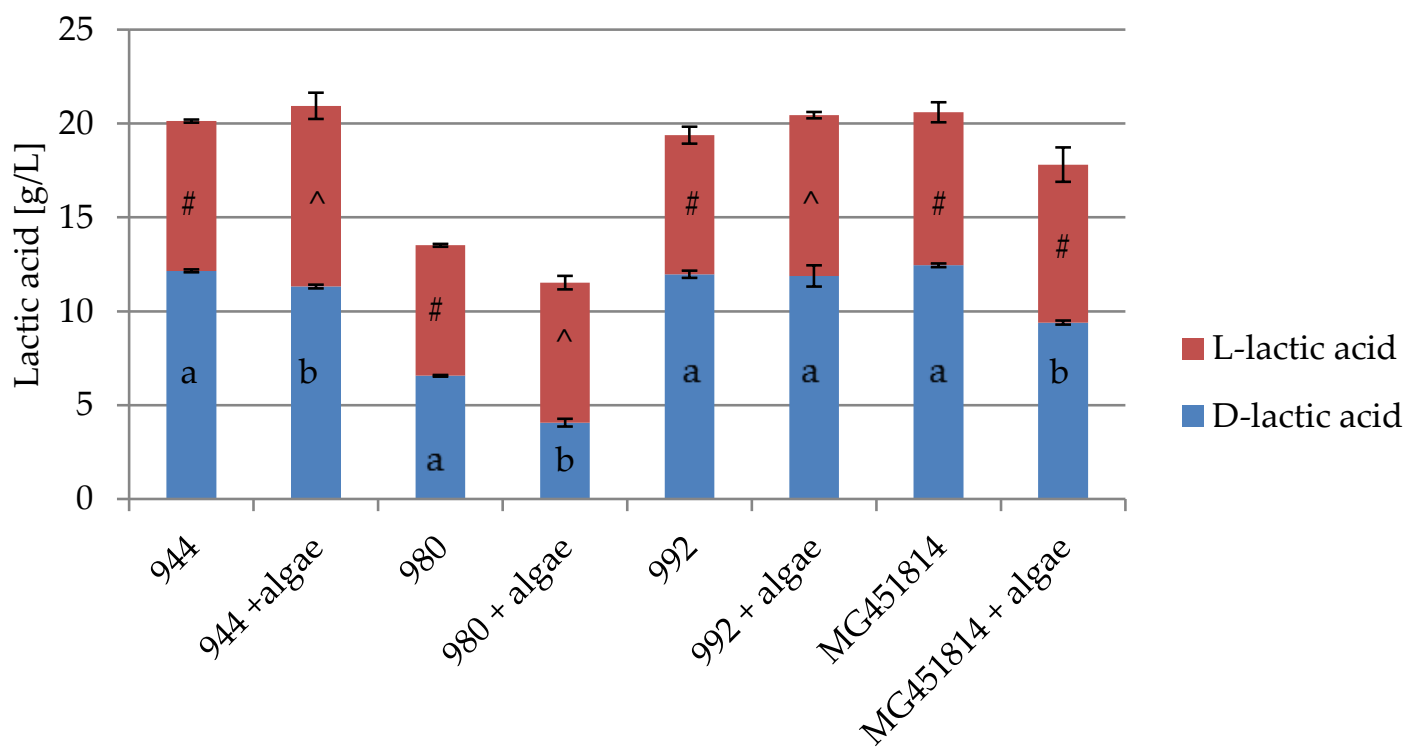

Figure 2. D- and L-lactic acid produced by Lactobacillus brevis ŁOCK 0944, 0980, 0992, and MG451814 cultured with and without algae Chlorella vulgaris. a, b-the statistically significant differences between samples of the same strains within one time interval for D-lactic acid; $p<0.05$; \#, —-the statistically significant differences between samples of the same strains within one time interval for L-lactic acid; $p<0.05 ; n=3$.

The highest amount of D-lactic acid was found for Lactobacillus brevis ŁOCK 0944 (12.15 g/L), while the lowest was Lactobacillus brevis ŁOCK $0980(6.56 \mathrm{~g} / \mathrm{L})$. The addition of Chlorella vulgaris to the LAB growth medium caused a decrease in the amount of D-lactic acid by all tested Lactobacillus brevis strains (statistically significant differences were observed for Lactobacillus brevis ŁOCK 0944, ŁOCK 0980, and MG451814). The highest difference in D-lactic acid production was observed by Lactobacillus brevis MG451814 (reduction by $3.05 \mathrm{~g} / \mathrm{L}$ ). The L-lactic acid production of the tested LAB strains was similar $(6.95-8.15 \mathrm{~g} / \mathrm{L})$. Lactobacillus brevis cultured in the presence of Chlorella vulgaris produced more L-lactic acid (statistically significant differences were observed for Lactobacillus brevis ŁOCK 0944, ŁOCK 0980, and ŁOCK 0992). The largest increase (by $1.65 \mathrm{~g} / \mathrm{L}$ ) was recorded for Lactobacillus brevis ŁOCK 0944.

\subsection{The Impact of Chlorella vulgaris on the Enzymatic Activity of Lactobacillus spp.}

The enzymatic activity of the Lactobacillus strains, which was measured by the API ${ }^{\circledR} \mathrm{ZYM}$, is demonstrated in Table 5. All tested bacteria showed high enzymatic activity ( $3-5$ on the API ${ }^{\circledR}$ ZYM scale) for leucine arylamidase and $\beta$-glucosidase. The valine arylamidase activity was high for two strains of Lactobacillus brevis (ŁOCK 0980 and MG451814), while, for the other two (Lactobacillus brevis ŁOCK 0944 and ŁOCK 0992), the activity for this aminopeptidase was low (2 on the API ${ }^{\circledR} \mathrm{ZYM}$ scale). High (5 on the API ${ }^{\circledR}$ ZYM scale) $\beta$-galactosidase activity was obtained for Lactobacillus brevis ŁOCK 0980 and MG451814, and high acid phosphatase activity was obtained for Lactobacillus brevis ŁOCK 0980. 
Table 5. Enzymatic profiles obtained by $\mathrm{API}^{\circledR} \mathrm{ZYM}$ for Lactobacillus strains cultured with and without the algae Chlorella vulgaris.

\begin{tabular}{|c|c|c|c|c|c|c|c|c|}
\hline Enzymes & 0944 & $\begin{array}{l}0944+ \\
\text { Algae }\end{array}$ & 0980 & $\begin{array}{l}0980+ \\
\text { Algae }\end{array}$ & 0992 & $\begin{array}{l}0992+ \\
\text { Algae }\end{array}$ & $\begin{array}{c}\text { MG } \\
451814\end{array}$ & $\begin{array}{c}\text { MG } \\
451814+\text { Algae }\end{array}$ \\
\hline Control & 0 & 0 & 0 & 0 & 0 & 0 & 0 & 0 \\
\hline Alkaline phosphatase & 0 & 0 & 0 & 0 & 0 & 0 & 0 & 0 \\
\hline Esterase (C 4) & 0 & 0 & 1 & 1 & 0 & 0 & 1 & 1 \\
\hline Esterase lipase (C 8) & 1 & 1 & 1 & 1 & 1 & 1 & 0 & 0 \\
\hline Lipase (C 14) & 0 & 0 & 0 & 0 & 0 & 0 & 0 & 0 \\
\hline Leucine arylamidase & 3 & 3 & 5 & 5 & 3 & 3 & 5 & 5 \\
\hline Valine arylamidase & 2 & 2 & 3 & 4 & 2 & 2 & 5 & 4 \\
\hline Cystine arylamidase & 0 & 0 & 0 & 0 & 0 & 0 & 1 & 0 \\
\hline Trypsin & 0 & 0 & 0 & 0 & 0 & 0 & 0 & 0 \\
\hline$\alpha$-chymotrypsin & 0 & 0 & 0 & 0 & 0 & 0 & 0 & 0 \\
\hline Acid phosphatase & 2 & 2 & 5 & 5 & 1 & 1 & 2 & 1 \\
\hline Naphthol-AS-bi-phosphohydrolase & 2 & 2 & 2 & 2 & 2 & 2 & 2 & 2 \\
\hline$\alpha$-galactosidase & 0 & 0 & 1 & 2 & 0 & 0 & 2 & 2 \\
\hline$\beta$-galactosidase & 0 & 0 & 5 & 5 & 0 & 1 & 5 & 5 \\
\hline$\beta$-glucuronidase & 0 & 0 & 0 & 0 & 0 & 0 & 0 & 0 \\
\hline$\alpha$-glucosidase & 1 & 0 & 1 & 4 & 0 & 0 & 2 & 2 \\
\hline$\beta$-glucosidase & 4 & 3 & 5 & 5 & 3 & 4 & 5 & 5 \\
\hline$N$-acetyl- $\beta$-glucosaminidase & 1 & 1 & 0 & 0 & 1 & 2 & 0 & 0 \\
\hline$\alpha$-mannosidase & 0 & 0 & 0 & 0 & 0 & 0 & 0 & 0 \\
\hline$\alpha$-fucosidase & 0 & 0 & 0 & 0 & 0 & 0 & 0 & 0 \\
\hline
\end{tabular}

The API ${ }^{\circledR}$ ZYM test scale was used for enzyme quantification, with 0 corresponding to a negative reaction/no activity and 5 corresponding to a maximum reaction $(3,4$, or 5 being considered positive reactions).

The addition of the algae Chlorella vulgaris at a concentration of $1.5 \%(w / v)$ to a LAB culture caused a decrease or an increase in enzymatic activity, depending on the strain. Lactobacillus brevis ŁOCK 0944 revealed lower $\alpha$-glucosidase and $\beta$-glucosidase activity, while Lactobacillus brevis MG451814 demonstrated lower valine arylamidase, cystine arylamidase, and acid phosphatase activity. However, Lactobacillus brevis ŁOCK 0980 cultured in the presence of Chlorella vulgaris showed higher enzymatic activity for valine arylamidase, $\alpha$-galactosidase, and $\alpha$-glucosidase, and Lactobacillus brevis ŁOCK 0992 for $\beta$-glucosidase and $N$-acetyl- $\beta$-glucosaminidase. The largest differences in the activity of LAB cultured in the presence of Chlorella vulgaris were observed for the $\alpha$-glucosidase activity of Lactobacillus brevis ŁOCK 0980, where the activity increased from 1 to 4 on the API ${ }^{\circledR}$ ZYM scale.

\section{Discussion}

The growth of LAB on conventional organic matrices such as cabbage, carrot, and milk has been measured by several authors [33-35]. They reported that the maximum concentrations reached by different species of Lactobacillus varied, ranging from 7 to $10 \log \mathrm{CFU} / \mathrm{mL}$. This is consistent with the results obtained in this study, where the maximum concentrations of the tested Lactobacillus brevis strains were 9.56-9.86 $\log$ CFU/mL. These results showed that the number of tested LAB cultured in MRS was observed to increase for up to $24 \mathrm{~h}$ of incubation. Similar results were reported by Matejčeková et al. [33], when incubating Lactobacillus plantarum at $37^{\circ} \mathrm{C}$. However, according to Bergqvist et al. [34], Lactobacillus pentosus isolated from cider extract demonstrated a stationary phase after about $9 \mathrm{~h}$; according to Li et al. [36], there was a stationary phase for Lactobacillus bulgaricus ATCC 11842 after about $10 \mathrm{~h}$. Moreover, studies by Yoon et al. [35] demonstrated that the viable cell counts of Lactobacillus casei, Lactobacillus plantarum, and Lactobacillus delbrueckii reached $8 \log \mathrm{CFU} / \mathrm{mL}$ after $24 \mathrm{~h}$ and increased to $9 \log \mathrm{CFU} / \mathrm{mL}$ after $48 \mathrm{~h}$ of fermentation at $30^{\circ} \mathrm{C}$. Moreover, they reached the conclusion that extending the fermentation beyond $48 \mathrm{~h}$ does not result in a significant increase in the viable cell counts of LAB. In contrast, the results of the current study showed a decrease in the number of LAB after $24 \mathrm{~h}$ of incubation for all tested strains (especially for Lactobacillus brevis ŁOCK 0944).

The effect of algae on the growth of LAB was also examined. A dynamic growth of Lactobacillus brevis biomass cultured in the presence of Chlorella vulgaris at concentrations of $0.1 \%(w / v)$ and $1.5 \%$ $(w / v)$ was observed for the first $18 \mathrm{~h}$ of culturing. The shortening of the logarithmic phase of LAB has great technological importance. Niccolai et al. [25] reached the maximum concentration of Lactobacillus plantarum ATCC 8014 cultivated with Arthrospira platensis (10.6 $\pm 0.2 \log$ CFU/mL) after $48 \mathrm{~h}$ of 
fermentation. Moreover, Lactobacillus bulgaricus ATCC 11842 cells grown in $2 \%$ algal carcass media (a by-product of biofuel production) was approximately $7 \log \mathrm{CFU} / \mathrm{mL}$; the control medium, MRS broth, provided better nutrient conditions for this LAB [36].

The results indicated that the acidifying activity of the Lactobacillus brevis varied depending on the strain of the bacteria. Similar results were obtained by Abbasiliasi et al. [37], who confirmed that the acidifying activity of Lactobacillus bulgaricus and Lactobacillus casei varied depending on the types and concentrations of bacteria. According to Yoon et al. [35], Lactobacillus plantarum and Lactobacillus delbrueckii produced significantly more titratable acidity than Lactobacillus casei. Moreover, the acidifying activity of the Lactobacillus brevis strain tested in this study increased with increasing concentrations of Chlorella vulgaris. Statistical analyses indicated that Chlorella vulgaris at a concentration of $1.5 \%$ $(w / v)$ had significant effects $(p<0.05)$ on the titratable acidity of all tested Lactobacillus brevis strains. Similar results were reported by Fadaei et al. [38], who found that the addition of Spirulina platensis into yogurt caused an increase in titratable acidity during $270 \mathrm{~min}$ of fermentation. The highest change in total acidity for all tested LAB occurred in the first $24 \mathrm{~h}$ of incubation, and the maximum concentrations were reached after $48 \mathrm{~h}$. Higher total acidity of samples with algae was probably due to the addition of Chlorella vulgaris, which stimulated the growth of Lactobacillus brevis. Moreover, the acidification of the broth can increase the LAB antagonist activity and lead to inhibition of the growth of pathogenic bacteria [39].

Furthermore, the addition of Chlorella vulgaris to the LAB growth medium caused a decrease in the amount of D-lactic acid production and increase the L-lactic acid production by all tested Lactobacillus brevis strains. It is worth noting that the metabolic conversion of L-lactic acid in the human body is faster than for D-lactic acid; therefore, L-lactic acid is preferred for use in food [40].

The authors investigated the enzymatic activity of Lactobacillus brevis. The results showed that all tested strains demonstrated high enzymatic activity for leucine arylamidase and $\beta$-glucosidase. Depending on the strain of Lactobacillus brevis, the valine arylamidase and acid phosphatase activities were higher or lower. Only two strains (Lactobacillus brevis ŁOCK 0980 and MG451814) demonstrated $\beta$-galactosidase activity. According to Mudryk and Podgórska [41], the level of leucine arylamidase activity is a good measure of the proteolytic activity of bacteria, as it is a peptide bond hydrolyzing enzyme. Abouloifa et al. [42] investigated the enzymatic activity of Lactobacillus brevis, Lactobacillus pentosus, and Lactobacillus plantarum isolated from traditional fermenting green olives. They found that all strains had a high enzymatic activity for leucine arylamidase and valine arylamidase, naphthol-AS-bi-phosphohydrolase, $\beta$-galactosidase, and $\beta$-glucosidase, while the $\alpha$-glucosidase activity was lower. Moreover, according to Abouloifa et al. [42], Lactobacillus brevis presented the highest $\beta$-galactosidase activity, a finding which was also confirmed by the results of this work. Furthermore, the high production of $\beta$-glucosidase was previously reported in Lactobacillus strains isolated from green olives [43].

The addition of Chlorella vulgaris to the Lactobacillus spp. culture at a concentration of $1.5 \%(w / v)$ changed their enzymatic activity. The largest differences in the activity of tested LAB cultured in the presence of algae was found for Lactobacillus brevis ŁOCK 0980, which showed higher enzymatic activity for valine arylamidase, $\alpha$-galactosidase, and $\alpha$-glucosidase. It is worth mentioning that $\beta$-glucosidase plays an important role in the bioconversion of oleuropein to hydroxytyrosol, which is a highly desired antioxidant in foods [43]. Moreover, microbial aminopeptidases provide more catalysis with a wide range of applications in the food industry. Aminopeptidase-mediated bioactive peptide synthesis is more preferable because the process is economical and ecofriendly [44]. Aminopeptidases have also been linked to flavor formation [45]. Therefore, the increased valine activity after introducing algae is a beneficial effect.

Considering the high concentration of LAB (9.63-9.83 $\log \mathrm{CFU} / \mathrm{mL})$ incubated with Chlorella vulgaris for $18 \mathrm{~h}$, the higher L-lactic acid production, and the lower D-lactic production, we can conclude that these algae are promising for the development of fermented foods. 


\section{Conclusions}

The effect of Chlorella vulgaris at concentrations of $0.1 \%(w / v)$ and $1.5 \%(w / v)$ on the growth of Lactobacillus brevis (ŁOCK 0944, ŁOCK 0980, ŁOCK 0992, and MG451814) was examined. The LAB strains reached the stationary phase after approximately $24 \mathrm{~h}$, though the addition of algae into the Lactobacillus spp. growth medium shortened their logarithmic phase (stationary phase after about $18 \mathrm{~h}$ ), which has great technological importance. The authors indicated that the total acidity of the LAB cultured in the presence of Chlorella vulgaris was higher. Moreover, the acidifying activity of Lactobacillus brevis increased with increased concentration of algae. The addition of Chlorella vulgaris to the LAB growth medium caused increased L-lactic acid production and decreased the amount of D-lactic acid produced by all tested Lactobacillus brevis strains. Chlorella vulgaris at a concentration of $1.5 \%(w / v)$ changed the enzymatic activity of the Lactobacillus spp. tested (for instance, the higher enzymatic activity for valine arylamidase, $\alpha$-galactosidase, and $\alpha$-glucosidase of Lactobacillus brevis ŁOCK 0980). The combination of Chlorella vulgaris and Lactobacillus brevis shows great potential for creating innovative, functional products that can provide a significant amount of lactic acid bacteria to the consumer, in addition to the nutritional properties of algae, thus conferring additional favorable properties to the final food product.

Author Contributions: Conceptualization, E.K. and S.Ś.; methodology, E.K. and S.Ś.; formal analysis S.Ś.; investigation, S.Ś.; writing—original draft preparation, S.Ś.; writing—review and editing, E.K.; visualization, E.K. and S.S.; supervision, E.K.; project administration, E.K. All authors have read and agreed to the published version of the manuscript.

Funding: This research received no external funding.

Conflicts of Interest: The authors declare no conflict of interest.

\section{References}

1. Lafarga, T. Effect of microalgal biomass incorporation into foods: Nutritional and sensorial attributes of the end products. Algal Res. 2019, 41, 101566. [CrossRef]

2. Caporgno, M.P.; Mathys, A. Trends in microalgae incorporation into innovative food products with potential health benefits. Front. Nutr. 2018, 5, 58. [CrossRef] [PubMed]

3. Zhang, J.; He, Y.; Luo, M.; Chen, F. Utilization of enzymatic cell disruption hydrolysate of Chlorella pyrenoidosa as potential carbon source in algae mixotrophic cultivation. Algal Res. 2020, 45, 101730. [CrossRef]

4. Graça, C.; Fradinho, P.; Sousa, I.; Raymundo, A. Impact of Chlorella vulgaris on the rheology of wheat flour dough and bread texture. LWT Food Sci. Technol. 2018, 89, 466-474. [CrossRef]

5. Uribe-Wandurraga, Z.N.; Igual, M.; García-Segovia, P.; Martínez-Monzó, J. Effect of microalgae addition on mineral content, colour and mechanical properties of breadsticks. Food Funct. 2019, 10, 4685-4692. [CrossRef]

6. Batista, A.P.; Niccolai, A.; Fradinho, P.; Fragoso, S.; Bursic, I.; Rodolfi, L.; Biondi, N.; Tredici, M.R.; Sousa, I.; Raymundo, A. Microalgae biomass as an alternative ingredient in cookies: Sensory, physical and chemical properties, antioxidant activity and in vitro digestibility. Algal Res. 2017, 26, 161-171. [CrossRef]

7. Beheshtipour, H.; Mortazavian, A.M.; Mohammadi, R.; Sohrabvandi, S.; Khosravi-Darani, K. Supplementation of Spirulina platensis and Chlorella vulgaris algae into probiotic fermented milks. Compr. Rev. Food Sci. Food Saf. 2013, 12, 144-154. [CrossRef]

8. Heo, J.-Y.; Shin, H.-J.; Oh, D.-H.; Cho, S.-K.; Yang, C.-J.; Kong, I.-K.; Lee, S.-S.; Choi, K.-S.; Choi, S.-H.; Kim, S.-C.; et al. Quality properties of Appenzeller cheese added with Chlorella. Korean J. Food Sci. Anim. Resour. 2006, 26, 525-531.

9. Tohamy, M.M.; Ali, M.A.; Shaaban, H.A.G.; Mohamad, A.G.; Hasanain, A.M. Production of functional spreadable processed cheese using Chlorella vulgaris. Acta Sci. Pol. Technol. Aliment. 2018, 17, 347-358. [CrossRef]

10. Carrizo, S.L.; de LeBlanc, A.D.M.; LeBlanc, J.G.; Rollán, G.C. Quinoa pasta fermented with lactic acid bacteria prevents nutritional deficiencies in mice. Food Res. Int. 2020, 127, 108735. [CrossRef] 
11. Vieco-Saiz, N.; Belguesmia, Y.; Raspoet, R.; Auclair, E.; Gancel, F.; Kempf, I.; Drider, D. Benefits and inputs from lactic acid bacteria and their bacteriocins as alternatives to antibiotic growth promoters during food-animal production. Front. Microb. 2019, 10, 57. [CrossRef] [PubMed]

12. EFSA Panel on Biological Hazards (BIOHAZ); Koutsoumanis, K.; Allende, A.; Álvarez-Ordóñez, A.; Bolton, D.; Bover-Cid, S.; Chemaly, M.; Davies, R.; Hilbert, F.; Lindqvist, R.; et al. Update of the list of QPS-recommended biological agents intentionally added to food or feed as notified to EFSA 9: Suitability of taxonomic units notified to EFSA until September 2018. Efsa J. 2019, 17, e05555. [CrossRef]

13. Ma, C.; Zhang, S.; Lu, J.; Zhang, C.; Pang, X.; Lv, J. Screening for cholesterol-lowering probiotics from lactic acid bacteria isolated from corn silage based on three hypothesized pathways. Int. J. Mol. Sci. 2019, 20, 2073. [CrossRef] [PubMed]

14. Khare, A.; Gaur, S. Cholesterol-Lowering effects of Lactobacillus species. Curr. Microb. 2020, 77, 638-644. [CrossRef]

15. Kim, J.A.; Kim, S.H.; Kim, I.S.; Yu, D.Y.; Kim, S.C.; Lee, S.H.; Lee, S.S.; Yun, C.-H.; Choi, I.S.; Cho, K.K. Anti-inflammatory effects of a mixture of lactic acid bacteria and sodium butyrate in atopic dermatitis murine model. J. Med. Food 2018, 21, 716-725. [CrossRef]

16. Pinteus, S.; Silva, J.; Alves, C.; Horta, A.; Fino, N.; Rodrigues, A.I.; Mendes, S.; Pedrosa, R. Cytoprotective effect of seaweeds with high antioxidant activity from the Peniche coast (Portugal). Food Chem. 2017, 218, 591-599. [CrossRef]

17. Tsai, C.C.; Lai, T.M.; Hsieh, Y.M. Evaluation of Lactobacilli for antagonistic activity against the growth, adhesion and invasion of Klebsiella pneumoniae and Gardnerella vaginalis. Indian J. Microb. 2019, 59, 81-89. [CrossRef]

18. Iorizzo, M.; Lombardi, S.J.; Ganassi, S.; Testa, B.; Ianiro, M.; Letizia, F.; Succi, M.; Tremonte, P.; Vergalito, F.; Cozzolino, A.; et al. Antagonistic Activity against Ascosphaera apis and Functional Properties of Lactobacillus kunkeei Strains. Antibiotics 2020, 9, 262. [CrossRef]

19. Mechai, A.; Debabza, M.; Zouari, S. Antagonistic activity of lactic acid bacteria isolated from Algerian traditional fermented milks against multi-drug resistant and $\beta$-lactamases-producing pathogenic bacteria. Res. J. Biotechnol. 2020, 15, 4.

20. Harper, A.; Naghibi, M.M.; Garcha, D. The Role of Bacteria, Probiotics and Diet in Irritable Bowel Syndrome. Foods 2018, 7, 13. [CrossRef]

21. Ellis, S.R.; Nguyen, M.; Vaughn, A.R.; Notay, M.; Burney, W.A.; Sandhu, S.; Sivamani, R.K. The Skin and Gut Microbiome and Its Role in Common Dermatologic Conditions. Microorganisms 2019, 7, 550. [CrossRef] [PubMed]

22. Huang, R.; Ning, H.; Shen, M.; Li, J.; Zhang, J.; Chen, X. Probiotics for the Treatment of Atopic Dermatitis in Children: A Systematic Review and Meta-Analysis of Randomized Controlled Trials. Front. Cell. Infect. Microbiol. 2017, 7, 392. [CrossRef] [PubMed]

23. Kim, J.H.; Kim, K.; Kim, W. Cream cheese-derived Lactococcus chungangensis CAU 28 modulates the gut microbiota and alleviates atopic dermatitis in BALB/c mice. Sci. Rep. 2019, 9, 1-13. [CrossRef] [PubMed]

24. Uchida, M.; Murata, M.; Ishikawa, F. Lactic acid bacteria effective for regulating the growth of contaminant bacteria during the fermentation of Undaria pinnatifida (Phaeophyta). Fish Sci. 2007, 73, 694-704. [CrossRef]

25. Niccolai, A.; Shannon, E.; Abu-Ghannam, N.; Biondi, N.; Rodolfi, L.; Tredici, M.R. Lactic acid fermentation of Arthrospira platensis (spirulina) biomass for probiotic-based products. J. Appl. Phycol. 2019, 31, 1077-1083. [CrossRef]

26. Gupta, S.; Abu-Ghannam, N.; Scannell, A.G. Growth and kinetics of Lactobacillus plantarum in the fermentation of edible Irish brown seaweeds. Food Bioprod. Process. 2011, 89, 346-355. [CrossRef]

27. Oh, S.T.; Zheng, L.; Kwon, H.J.; Choo, Y.K.; Lee, K.W.; Kang, C.W.; An, B.K. Effects of dietary fermented Chlorella vulgaris $\left(\mathrm{CBT}^{\circledR}\right)$ on growth performance, relative organ weights, cecal microflora, tibia bone characteristics, and meat qualities in Pekin ducks. Asian Australas. J Anim. Sci. 2015, 28, 95. [CrossRef]

28. Loveday, S.M. Food proteins: Technological, nutritional, and sustainability attributes of traditional and emerging proteins. Annu. Rev. Food Sci. Technol. 2019, 10, 311-339. [CrossRef]

29. Saadat, Y.R.; Khosroushahi, A.Y.; Gargari, B.P. A comprehensive review of anticancer, immunomodulatory and health beneficial effects of the lactic acid bacteria exopolysaccharides. Carbohydr. Polym. 2019, 217, 79-89. [CrossRef] 
30. Noda, M.; Danshiitsoodol, N.; Inoue, Y.; Okamoto, T.; Sultana, N.; Sugiyama, M. Antibiotic susceptibility of plant-derived lactic acid bacteria conferring health benefits to human. J. Antibiot. 2019, 72, 834-842. [CrossRef]

31. Shannon, E.; Abu-Ghannam, N. Seaweeds as nutraceuticals for health and nutrition. Phycologia 2019, 58, 563-577. [CrossRef]

32. Klewicka, E.; Libudzisz, Z.; Śliżewska, K.; Otlewska, A. A New Strain of Lactic Acid Bacteria Lacobacillus brevis. Patent No. PL 214504, B1, 30 August 2013.

33. Matejčeková, Z.; Liptáková, D.; Spodniaková, S.; Valík, L'. Characterization of the growth of Lactobacillus plantarum in milk in dependence on temperature. Acta Chim. Slov. 2016, 9, 104-108. [CrossRef]

34. Bergqvist, S.W.; Sandberg, A.S.; Carlsson, N.G.; Andlid, T. Improved iron solubility in carrot juice fermented by homo-and hetero-fermentative lactic acid bacteria. Food Microbiol. 2005, 22, 53-61. [CrossRef]

35. Yoon, K.Y.; Woodams, E.E.; Hang, Y.D. Production of probiotic cabbage juice by lactic acid bacteria. Biores. Technol. 2006, 97, 1427-1430. [CrossRef] [PubMed]

36. Li, C.; Zhang, G.F.; Mao, X.; Wang, J.Y.; Duan, C.Y.; Wang, Z.J.; Liu, L.B. Growth and acid production of Lactobacillus delbrueckii ssp. bulgaricus ATCC 11842 in the fermentation of algal carcass. J. Dairy Sci. 2016, 99, 4243-4250. [CrossRef]

37. Abbasiliasi, S.; Marikkar, M.N.; Ariff, A.; Amid, M.; Lamasudin, D.U.; Manap, M.Y.A.; Mustafa, S. Defatted coconut residue crude polysaccharides as potential prebiotics: Study of their effects on proliferation and acidifying activity of probiotics in vitro. J. Food Sci. Technol. 2017, 54, 164-173. [CrossRef]

38. Fadaei, V.; Eslami-Moshkenani, A.; Khosravi-Darani, K. Effects of powdered Spirulina platensis biomass on $\mathrm{pH}$ and titratable acidity of probiotic doogh containing powdered mint during cold storage. Int. J. Biol. Biotechnol. 2013, 10, 631-635.

39. Gavrilova, E.; Anisimova, E.; Gabdelkhadieva, A.; Nikitina, E.; Vafina, A.; Yarullina, D.; Bogachev, M.; Kayumov, A. Newly isolated lactic acid bacteria from silage targeting biofilms of foodborne pathogens during milk fermentation. BMC Microb. 2019, 19, 248. [CrossRef]

40. Komesu, A.; de Oliveira, J.A.R.; da Silva Martins, L.H.; Maciel, M.R.W.; Maciel Filho, R. Lactic acid production to purification: A review. BioResources 2017, 12, 4364-4383. [CrossRef]

41. Mudryk, Z.J.; Podgorska, B. Enzymatic Activity of Bacterial Strains Isolated from Marine Beach Sediments. Pol. J. Environ. Stud. 2006, 15, 441-448.

42. Abouloifa, H.; Rokni, Y.; Bellaouchi, R.; Ghabbour, N.; Karboune, S.; Brasca, M.; Salah, R.B.; Chihib, N.E.; Saalaoui, E.; Asehraou, A. Characterization of probiotic properties of antifungal Lactobacillus strains isolated from traditional fermenting green olives. Probiotics Antimicro. Prot. 2020, 12, 683-696. [CrossRef] [PubMed]

43. Ghabbour, N.; Lamzira, Z.; Thonart, P.; Cidalia, P.; Markaoui, M.; Asehraou, A. Selection of oleuropein-degrading lactic acid bacteria strains isolated from fermenting Moroccan green olives. Grasas y Aceites 2011, 62, 84-89. [CrossRef]

44. Nandan, A.; Nampoothiri, K.M. Therapeutic and biotechnological applications of substrate specific microbial aminopeptidases. Appl. Microbiol. Biotechnol. 2020, 1-15. [CrossRef] [PubMed]

45. Domingos-Lopes, M.F.P.; Stanton, C.; Ross, P.R.; Dapkevicius, M.L.E.; Silva, C.C.G. Genetic diversity, safety and technological characterization of lactic acid bacteria isolated from artisanal Pico cheese. Food Microbiol. 2017, 63, 178-190. [CrossRef]

(C) 2020 by the authors. Licensee MDPI, Basel, Switzerland. This article is an open access article distributed under the terms and conditions of the Creative Commons Attribution (CC BY) license (http://creativecommons.org/licenses/by/4.0/). 